\title{
Enriched, HIMU-type peridotite and depleted recycled pyroxenite in the Canary plume: a mixed-up mantle
}

Andrey A. Gurenko ${ }^{\mathrm{a}, \mathrm{b}, *}$, Alexander V. Sobolev ${ }^{\mathrm{a}, \mathrm{c}}$, Kaj A. Hoernle ${ }^{\mathrm{d}}$, Folkmar Hauff ${ }^{\mathrm{d}}$, and HansUlrich Schmincke $^{\mathrm{d}}$

${ }^{a}$ Max-Planck-Institut für Chemie, Abteilung Geochemie, Postfach 3060, D-55020 Mainz, Germany

${ }^{\mathrm{b}}$ Woods Hole Oceanographic Institution, Geology and Geophysics, Woods Hole, MA 02543, USA

${ }^{c}$ Vernadsky Institute of Geochemistry and Analytical Chemistry, Kosigin Str. 19, 119991 Moscow, Russia

d IfM-GEOMAR Leibniz Institute for Marine Sciences, Dynamics of the Ocean Floor, Wischhofstraße 1-3, D-24148 Kiel, Germany

Manuscript accepted for publication in Earth and Planetary Science Letters

November, 2008

\section{Components:}

abstract - 280 words; 1,834 characters with spaces;

main text $-6,330$ words; 41,109 characters with spaces;

5 figures, 2 tables;

list of references includes 60 citations.

\section{* Corresponding author and present address:}

Andrey Gurenko, Woods Hole Oceanographic Institution, Clark 114, MS\#23, Woods Hole, MA 02543, USA; Phone: +1 508 289-2405, Fax: +1 508-457-2175; E-mail: agurenko@,whoi.edu 
Abstract - The Earth's mantle is chemically and isotopically heterogeneous, and a component of recycled oceanic crust is generally suspected in the convecting mantle [Hofmann and White, 1982. Mantle plumes from ancient oceanic crust. Earth Planet. Sci. Lett. 57, 421-436]. Indeed, the HIMU component (high $\mu={ }^{238} \mathrm{U} /{ }^{204} \mathrm{~Pb}$ ), one of four isotopically distinct end-members in the Earth's mantle, is generally attributed to relatively old $(\geq 1-2 \mathrm{Ga})$ recycled oceanic crust in the form of eclogite/pyroxenite, e.g. [Zindler and Hart, 1986. Chemical geodynamics. Ann. Rev. Earth Planet. Sci. 14, 493-571]. Although the presence of the recycled component is generally supported by element and isotopic data, little is known about its physical state at mantle depths. Here we show that the concentrations of $\mathrm{Ni}, \mathrm{Mn}$ and $\mathrm{Ca}$ in olivine from the Canarian shield stage lavas, which can be used to asses the physical nature of the source material (peridotite versus olivine-free pyroxenite) [Sobolev et al., 2007. The amount of recycled crust in sources of mantle-derived melts. Science 316, 412-417], correlate strongly with bulk rock $\mathrm{Sr}, \mathrm{Nd}$ and $\mathrm{Pb}$ isotopic ratios. The most important result following from our data is that the enriched, HIMU-type (having higher ${ }^{206} \mathrm{~Pb} /{ }^{204} \mathrm{~Pb}$ than generally found in the other mantle endmembers) signature of the Canarian hotspot magmas was not caused by a pyroxenite/eclogite constituent of the plume but appears to have been primarily hosted by peridotite. This implies that the old (older than $\sim 1 \mathrm{Ga}$ ) ocean crust, which has more evolved radiogenic isotope compositions, was stirred into/reacted with the mantle so that there is not significant eclogite left, whereas younger recycled oceanic crust with depleted MORB isotopic signature $(<1 \mathrm{Ga})$ can be preserved as eclogite, which when melted can generate reaction pyroxenite.

Keywords: Canary Islands, mantle plume, pyroxenite, olivine, radiogenic isotopes 


\section{Introduction}

Identification and mixing proportions of components contributing to the origin of mafic magmas is one of the major geochemical challenges in understanding the dynamics of the Earth's mantle. The presence of recycled oceanic crust in the Earth's convecting mantle (Hofmann and White, 1982; White and Hofmann, 1982; Allègre and Turcotte, 1986) is now generally accepted. The origin of the HIMU endmember (high $\mu={ }^{238} \mathrm{U} /{ }^{204} \mathrm{~Pb}$ ), one of four isotopic end-members in the mantle, is generally attributed to old ( 2 Ga) recycled oceanic crust (Zindler et al., 1982; White, 1985; Zindler and Hart, 1986). Mafic lavas with ${ }^{206} \mathrm{~Pb} /{ }^{204} \mathrm{~Pb}$ isotope ratios higher than normal midocean-ridge basalt (N-MORB) but lower than endmember HIMU that fall beneath the Northern Hemisphere Reference Line (NHRL; after Hart, 1984) on the uranogenic Pb isotope diagram can be explained by the recycling of ocean crust for shorter time periods ( $<2 \mathrm{Ga}$; Thirlwall, 1997).

Sobolev et al. $(2005,2007)$ proposed a method that allows the quantitative reconstruction of the amount of the recycled component in the ascending mantle. This method is based on the coherent variations of $\mathrm{Ni}$ and $\mathrm{Mn}$ in olivine phenocrysts, reflecting the relative contributions of the pure peridotite mantle and the recycled (eclogitic) component. In more detail, Si-rich melts formed during partial melting of eclogite, the high-P product of subducted oceanic crust, react with ambient peridotitic mantle, converting it to olivine-free pyroxenite. Partial melting of such "reaction" pyroxenite results in melts higher in $\mathrm{Ni}$ but poorer in $\mathrm{Mn}$ (and $\mathrm{Ca}$ ) concentrations than melts generated from peridotite alone, because $\mathrm{Ni}$ and $\mathrm{Mn}$ (and $\mathrm{Ca}$ ) behave differently during partial melting in the presence of olivine and pyroxene. Nickel is more compatible in olivine, while Mn and Ca preferentially partition into ortho- and clinopyroxene (e.g., Hart and Davis, 1978; Beattie et al., 1991, Humayun et al., 2004; Wang and Gaetani, 2008). Finally, a source consisting of different

proportions of peridotite and pyroxenite will yield a "hybrid melt". The relative contributions of peridotite and pyroxenite can be inferred from $\mathrm{Ni}$ and $\mathrm{Mn}$ concentrations in olivine phenocrysts crystallized from this hybrid magma at shallower depths. If this basic assumption is correct, we would expect coherent relationships between chemical compositions of olivine phenocrysts (expressed in terms of $\mathrm{Ni}, \mathrm{Mn}$ and $\mathrm{Ca}$ concentrations) and bulk rock compositions of the host lavas. 
Using this approach, Sobolev et al. (2008) have recently shown that the enriched component at Iceland is derived from ancient recycled ocean crust (eclogite forming reaction pyroxenite), whereas the depleted component is likely to be derived from a peridotitic MORB source.

The lavas from the Canary Islands, Spain (Fig. 1), are believed to be derived from decompression melting of a mantle plume carrying an isotopically enriched, HIMU-type component originating from recycled oceanic lithosphere (e.g., Hoernle and Tilton, 1991; Hoernle et al., 1991; Thirlwall, 1997; Widom et al., 1999; Lundstrom et al., 2003; Gurenko et al., 2006). The trace element and isotope geochemistry of mafic $\left(\mathrm{MgO}>10 \mathrm{wt} \%\right.$ ), low-silica $\left(\mathrm{SiO}_{2}<46\right.$ wt.\%) lavas from throughout the Canary Islands form arrays between a HIMU-like end-member and N-MORB, interpreted to reflect interaction of plume melts with depleted upper mantle (e.g., Hoernle et al., 1991, 1995), or mixing between older (HIMU-like) and younger (MORB-like) recycled oceanic crustal components either within the plume (Widom et al., 1999) or in upwelling asthenosphere (Geldmacher et al., 2005).

Mafic high-silica $\left(\mathrm{SiO}_{2}>46\right.$ wt.\%) and evolved magmas erupted on the eastern Canary Islands (i.e., Lanzarote, Fuerteventura, Gran Canaria and Anaga Massif on Tenerife) also show evidence for the presence of enriched-mantle (EM)-type components (e.g., Hoernle and Tilton, 1991; Hoernle et al., 1991, 1995; Widom et al., 1999; Simonsen et al., 2000; Lundstrom et al., 2003). This component not only occurs in rocks from the eastern Canary Islands, but also in the seamounts belonging to the older parts of the Madeira and Canary hotspot tracks and the southeast Cape Verde Islands, i.e. in the parts of the hotspot products closest to African and European continents, irrespective of the age of the volcanism. Therefore, in most models for the origin of the EM-type components, they are ultimately related to/derived from the continental lithosphere, whether this be in the form of crustal splinters beneath the islands/seamounts or recycled subcontinental lithospheric mantle incorporated in the upper mantle beneath the volcanic structures closest to the continents, i.e. within lithospheric mantle, uppermost asthenosphere directly beneath the lithosphere and/or deeper portions of the upper mantle, where it can be entrained by rising plumes (e.g., Gerlach et al., 1988; Hoernle and Tilton, 1991; Hoernle et al., 1991, 1995, 2002; 
Widom et al., 1999; Geldmacher and Hoernle, 2000; Lundstrom et al., 2003; Doucelance et al., 2003; Escrig et al., 2005; Geldmacher et al., 2005). Recently, Geldmacher et al. (2008) have confirmed a shallow origin for at least some of the EM-type components in the northern Atlantic and provide evidence for the origin of EM-type mantle through recycling of subcontinental lithosphere globally. In conclusion, most studies of intraplate volcanism in the eastern Atlantic favor an origin of the EM-type components through plume - upper mantle (lithosphere and/or asthenosphere) interaction. Due to the added geochemical complexity of the eastern Canary Islands, i.e. evidence for ubiquitous involvement of enriched (EM-type) mantle components in the generation of their shield-stage lavas, we focused this study on the western Canary Islands (excluding the Anaga Shield on Tenerife, which also shows evidence of involvement of an EM-type component).

Here we present data on the compositions of olivine phenocrysts from the most primitive picritic to basaltic lavas from the shield stages of the four westernmost Canary Islands (going from east to west: Tenerife, La Gomera, La Palma and El Hierro). We demonstrate that the concentrations of $\mathrm{Ni}, \mathrm{Mn}$ and $\mathrm{Ca}$ in olivine correlate with bulk rock $\mathrm{Sr}, \mathrm{Nd}$ and $\mathrm{Pb}$ isotopic compositions of their host lavas, indicating that the "HIMU"-like component of the Canary plume is derived from a peridotitic source and the depleted component from a pyroxenitic component derived from younger (probably less than $\sim 1 \mathrm{Ga}$ ) recycled oceanic crust.

\section{Geological setting and studied samples}

The Canary Archipelago (Fig. 1) has an unusually long magmatic history ranging from at least $20 \mathrm{Ma}$ (possibly from the Late Cretaceous) in the eastern Canaries through 12-16 Ma in the central part of the archipelago to ca. less than 1 to $4 \mathrm{Ma}$ on the westernmost islands, representing an age-progressive $\sim 500 \mathrm{~km}$ long island chain (e.g., Abdel-Monem et al., 1971, 1972; Schmincke, 1982; Guillou et al., 1996; Schmincke and Sumita, 1998). Volcanic rocks from the Canary Islands display an exceptionally large compositional range, including tholeiites, alkali basalt through trachyte and peralkaline rhyolite, basanite and nephelinite through phonolite (Fúster et al., 1968; 
Ibarrola, 1970; Hoernle and Schmincke, 1993). In contrast to the Hawaiian Islands, tholeiitic lavas are extremely rare on the Canary Islands, occurring only in the late or rejuvenated stages on the easternmost islands (including the second most voluminous tholeiitic eruption in historic times 1770 to 1776 - on Lanzarote), whereas picrobasalt, alkali basalt and basanite are the most common rock types, also during the shield stage volcanism when most of the volcanic edifices are formed.

We analyzed more than 1000 individual olivine crystals from 16 subaerially erupted picrobasalts from Tenerife, La Gomera and La Palma and three basanites from El Hierro representing the shield-building stage of the islands (the analytical details are given in the Online Supplementary information). Major and trace elements of El Hierro lavas are presented in Lundstrom et al. (2003), while elemental and Sr-Nd-Pb isotope data, except for EH4, EH8 and EH11 samples from El Hierro, were published in Gurenko et al. (2006). Strong variations in Ni concentrations in whole rocks are common ( 200-1000 ppm Ni at $\sim 10-30 \mathrm{wt} \% \mathrm{MgO}$; Lundstrom et al., 2003; Gurenko et al., 2006). The lavas are moderately enriched in light rare earth elements (REE), $\mathrm{Nb}$, Ta, and show relative depletions in $\mathrm{K}$ and $\mathrm{Pb}$, resembling HIMU-type magmas from ocean islands. The studied samples display relatively restricted ranges in ${ }^{87} \mathrm{Sr} /{ }^{86} \mathrm{Sr}(0.7030-0.7033)$ and ${ }^{143} \mathrm{Nd} /{ }^{144} \mathrm{Nd}(0.51288-0.51293)$ but a large range in $\mathrm{Pb}$ isotope ratios $\left({ }^{206} \mathrm{~Pb} /{ }^{204} \mathrm{~Pb}=19.49-20.27\right.$, ${ }^{207} \mathrm{~Pb} /{ }^{204} \mathrm{~Pb}=15.59-15.66,{ }^{208} \mathrm{~Pb} /{ }^{204} \mathrm{~Pb}=39.21-39.81$ ) (Gurenko et al., 2006; Table S1, Online Supplementary information). The ${ }^{87} \mathrm{Sr} /{ }^{86} \mathrm{Sr}$ and ${ }^{207} \mathrm{~Pb} /{ }^{204} \mathrm{~Pb}$ isotope ratios plotted against ${ }^{206} \mathrm{~Pb} /{ }^{204} \mathrm{~Pb}$ ratios form positive arrays, whereas ${ }^{143} \mathrm{Nd} /{ }^{144} \mathrm{Nd}$ versus ${ }^{206} \mathrm{~Pb} /{ }^{204} \mathrm{~Pb}$ form negative arrays (Fig. 2). The arrays extend from MORB (or depleted, MORB-like source mantle, DMM) to the low-velocity component (LVC) with HIMU affinities, representing a common plume component found in intraplate volcanic rocks throughout the eastern Atlantic, western Mediterranean and Western Europe (Hoernle et al., 1995).

\section{Results}

\subsection{Composition of olivine phenocrysts}


The forsterite (Fo) contents, $\mathrm{Ni}, \mathrm{Mn}$ and $\mathrm{Ca}$ concentrations and $\mathrm{Ni} \times \mathrm{FeO} / \mathrm{MgO}$ and $\mathrm{Mn} / \mathrm{FeO}$ ratios of olivine $(\mathrm{Ol})$ phenocrysts together with bulk-rock radiogenic isotope data are summarized in Table 1. Olivine compositions range from $\mathrm{Fo}_{72.1-86.3}$ at Tenerife, $\mathrm{Fo}_{78.9-89.6}$ at $\mathrm{La}$ Gomera, $\mathrm{Fo}_{81.2-87.0}$ at La Palma and $\mathrm{Fo}_{76.3-86.1}$ at El Hierro, almost entirely overlapping the range reported by Gurenko et al. (2006) obtained on a larger number of samples (individual olivine analyses are given in Table S2, Online Supplementary information). Here we consider only the most Mg-rich olivines, defined by 3 mol.\% Fo of the highest Fo value in each individual sample (Figs. 3 and S1, Online Supplementary information). We observe large, systematic inter- and intra-island variations in olivine Fo contents and in concentrations of minor elements such as $\mathrm{Ca}, \mathrm{Ni}, \mathrm{Mn}$ and $\mathrm{Cr}$. These variations significantly exceed the obtained $\pm 2 \sigma \mathrm{SD}$ analytical errors $( \pm 0.1 \mathrm{~mol} \%$ Fo, $\pm 70-80 \mathrm{ppm}$ for $\mathrm{Ca}$ and $\mathrm{Ni}$, and $\pm 40 \mathrm{ppm}$ for $\mathrm{Mn}$ and $\mathrm{Cr}$ concentrations, respectively).

Nickel concentrations (1358-2160 ppm Ni from Tenerife, 1377-3465 ppm Ni from La Gomera, 1497-2407 ppm Ni from La Palma and 1473-2945 ppm Ni from El Hierro; Fig. S1a, Online Supplementary information), generally decrease with decreasing Fo values due to magma fractionation, but vary significantly at any given Fo value. Similar variations of Ni in olivine were described by Sobolev et al. (2005) for Hawaiian lavas and also for olivines world-wide (Sobolev et al., 2007). It should be noted that although there is considerable overlap in the Ni contents for olivines from Tenerife, La Gomera and La Palma at a given Fo content, Ni in olivines from El Hierro are almost always higher at a given Fo content than for the other islands.

Manganese strongly correlates with Fo contents (Fig. S1b, Online Supplementary information). The observed variations exceed the EPMA analytical error by about two to three times for $\mathrm{Mn}$ (i.e., reproducibility of SCOL in the Mn-Fo space) and thus are likely to represent true variations. Several distinct trends of Mn concentrations vs. Fo contents are observed. In particular, the Tenerife and La Gomera olivine data define several subsets forming sub-parallel trends, while La Palma and El Hierro exhibit single trends, showing somewhat stronger dispersion. The El Hierro olivines generally have the lowest $\mathrm{Mn}$ at a given Fo content. 
Most olivine compositions are characterized by Ca concentrations between 1000 and 3000 ppm typical for Ol crystallized from basaltic magmas (Fig. S1c, Online Supplementary information). Olivines from different Canary Islands form individual but overlapping groups with respect to $\mathrm{Ca}$. Most olivines from $\mathrm{El}$ Hierro basanites are characterized by the lowest $\mathrm{Ca}$ concentrations $(<1700 \mathrm{ppm})$, forming a group distinct from olivines from the other islands. Shallowlevel fractional crystallization and a relatively narrow range of parental magma compositions cannot produce such a large Ca range (see discussion below). This observation is essential, because, as

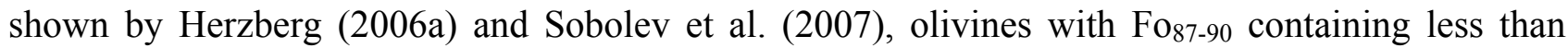
2000 ppm Ca are unlikely to have crystallized from peridotite-derived melts and thus may indicate a higher contribution of melts originating from pyroxene-rich lithologies.

Chromium shows a strong positive correlation with Fo, whose variations are several times larger than the analytical error (Fig. S1d, Online Supplementary information). The highest concentrations of ca. 300-600 ppm Cr observed in olivines Fo $87-90$ correspond to those in $\mathrm{Ol}$ from mid-ocean-ridge and intra-plate basaltic rocks but are much lower than those in $\mathrm{Ol}$ from komatiites (for reference fields see Sobolev et al., 2007). Since the concentrations of $\mathrm{Cr}$ are strongly controlled by the presence of residual garnet and/or spinel in the peridotite source (Sobolev et al., 2007 and reference therein), we conclude that the magma source rocks beneath the Canary Islands may contain varying proportions of garnet and spinel, as was demonstrated on the basis of petrologic data and major and trace element variations (Gurenko et al., 1996, 1998, 2006).

In order to minimize the effects of $\mathrm{Ol}$ fractionation on $\mathrm{Ni}$ and $\mathrm{Mn}$ contents, we henceforth use $\mathrm{Ni}$ and $\mathrm{Mn}$ concentrations (given in ppm) normalized to $\mathrm{FeO}$ and $\mathrm{MgO}$ contents (in wt.\%) (i.e., $\mathrm{Ni} \times \mathrm{FeO} / \mathrm{MgO}$ and $\mathrm{Mn} / \mathrm{FeO})$ using the approach of Sobolev et al. (2007, 2008). These ratios do not vary solely as a function of Fo content but range considerably at a given Fo number resembling the original $\mathrm{Ni}$ and $\mathrm{Mn}$ variations (Fig. 3) and correlate negatively with each other (not shown). In summary, at a given Fo content, olivines from La Gomera, La Palma and Tenerife have Ni, Mn and $\mathrm{Ca}$ concentrations and $\mathrm{Ni} \times \mathrm{FeO} / \mathrm{MgO}$ and $\mathrm{Mn} / \mathrm{FeO}$ ratios which largely overlap, whereas the $\mathrm{El}$ Hierro olivines generally have the lowest $\mathrm{Ca}, \mathrm{Mn}$ and $\mathrm{Mn} / \mathrm{FeO}$ but highest $\mathrm{Ni}$ and $\mathrm{Ni} \times \mathrm{FeO} / \mathrm{MgO}$. 


\subsection{Relationships between Ol composition and radiogenic isotopes}

The $\mathrm{Ni} \times \mathrm{FeO} / \mathrm{MgO}, \mathrm{Mn} / \mathrm{FeO}$ ratios and $\mathrm{Ca}$ concentrations of olivine phenocrysts averaged for each individual lava sample were plotted against bulk rock $\mathrm{Sr}, \mathrm{Nd}$ and $\mathrm{Pb}$ isotopic compositions of their host lavas. Positive correlations of $\mathrm{Ni} \times \mathrm{FeO} / \mathrm{MgO}$ ratios with ${ }^{143} \mathrm{Nd} /{ }^{144} \mathrm{Nd}$ and negative with ${ }^{87} \mathrm{Sr} /{ }^{86} \mathrm{Sr},{ }^{206} \mathrm{~Pb} /{ }^{204} \mathrm{~Pb},{ }^{207} \mathrm{~Pb} /{ }^{204} \mathrm{~Pb}$ and ${ }^{208} \mathrm{~Pb} /{ }^{204} \mathrm{~Pb}$ isotopic ratios are observed (Figs. 4 and $\mathrm{S} 2$, Online Supplementary information). In contrast, $\mathrm{Mn} / \mathrm{FeO}$ ratios and $\mathrm{Ca}$ concentrations display the opposite trends. Here we consider the following points to be significant:

(1) Olivines from La Gomera, La Palma, Tenerife extend to the highest $\mathrm{Mn} / \mathrm{FeO}$ and $\mathrm{Ca}$ but lowest $\mathrm{Ni} \times \mathrm{FeO} / \mathrm{MgO}$, whereas olivines from El Hierro have the highest $\mathrm{Ni} \times \mathrm{FeO} / \mathrm{MgO}$ and the lowest $\mathrm{Ca}$ and $\mathrm{MnO} / \mathrm{FeO}$ (Figs. 3 and S1, Online Supplementary information).

(2) On diagrams relating ${ }^{206} \mathrm{~Pb} /{ }^{204} \mathrm{~Pb}$ versus ${ }^{87} \mathrm{Sr} /{ }^{86} \mathrm{Sr},{ }^{143} \mathrm{Nd} /{ }^{144} \mathrm{Nd}$ and ${ }^{207} \mathrm{~Pb} /{ }^{204} \mathrm{~Pb}$ isotope ratios (Fig. 2), the shield stage samples from the four westernmost Canary Islands form simple two-component mixing arrays. The first is a HIMU-type component or LVC (low-velocity component, as defined by Hoernle et al., 1995) with relatively radiogenic $\mathrm{Pb}$ and $\mathrm{Sr}$ but unradiogenic $\mathrm{Nd}$ isotope ratios, and the second is a depleted MORB (or MORB source $=\mathrm{DMM}$ ) type component with the least radiogenic $\mathrm{Pb}$ and $\mathrm{Sr}$ but most radiogenic $\mathrm{Nd}$ isotopic composition. Similar conclusions follow from the linear relationships of $\mathrm{Ni} \times \mathrm{FeO} / \mathrm{MgO}, \mathrm{Mn} / \mathrm{FeO}$ ratios and $\mathrm{Ca}$ concentrations in olivine and radiogenic isotope ratios (Figs. 4 and S2, Online Supplementary information) i.e., at least two distinct components with distinct lithologies are required.

(3) No clear relationships are observed between averaged Fo content of the most Mg-rich olivines (as defined above) and radiogenic isotope values arguing against possible contamination of magma during fractionation. In addition, average Fo content also does not correlate with $\mathrm{Ni} \times \mathrm{FeO} / \mathrm{MgO}, \mathrm{Mn} / \mathrm{FeO}$ ratios, absolute $\mathrm{Ca}$ concentrations, and commonly referred to "uniform" trace element ratios such as $\mathrm{Ce} / \mathrm{Pb}, \mathrm{Nb} / \mathrm{La}, \mathrm{Nb} / \mathrm{U}$ or $\mathrm{Nb} / \mathrm{Th}$ (Hofmann, 2003). The whole rock compositions of the lavas studied $(\mathrm{Ce} / \mathrm{Pb}=$ 
23.8-43.7, $\mathrm{Nb} / \mathrm{La}=1.0-1.4, \mathrm{Nb} / \mathrm{U}=38.3-65.9$ and $\mathrm{Nb} / \mathrm{Th}=9.4-17.6$, except for one $\mathrm{La}$ Gomera sample with $\mathrm{Nb} / \mathrm{U}=78.3$, probably reflecting $\mathrm{U}$ mobilization in this older sample) correspond to the field of typical MORB and OIB reported by Hofmann (2003) but extend to somewhat higher $\mathrm{Ce} / \mathrm{Pb}$ values than those proposed for global MORB and OIB by Hofmann et al. (1986; i.e., $\mathrm{Ce} / \mathrm{Pb}=25 \pm 5$ ), as is commonly observed in HIMUtype volcanic rocks.

\section{Discussion}

\subsection{Evidence supporting the "reaction pyroxenite" model}

The concentrations of $\mathrm{Ni}$ and $\mathrm{Mn}$ in early crystallized olivine crystals and coexisting melts were used initially to quantify the amount of recycled material in the Hawaiian plume (Sobolev et al., 2005) and subsequently to demonstrate that the amount of recycled component, though highly variable, appears to be significant in the sources of most mantle-derived magmas worldwide (Sobolev et al., 2007). The approach is based on the remarkable decrease of Ni compatibility in the solid residue due to transformation of typical peridotite lithology (olivine + orthopyroxene + clinopyroxene \pm garnet \pm spinel) to olivine-free pyroxenite (clinopyroxene \pm orthopyroxene \pm garnet \pm spinel) and coherent increase of $\mathrm{Mn}$ relative to $\mathrm{Fe}$ incompatibility in the olivine-free restite (Hart and Davis, 1978; Beattie et al., 1991, Humayun et al., 2004). Partial melting of such pyroxene-rich and olivine-free rocks produces melts enriched in $\mathrm{Ni}$ but depleted in $\mathrm{Ca}$ and $\mathrm{Mn}$ compared to their peridotite-derived counterparts. Mixing with peridotite-derived melts and subsequent crystallization of such hybrid magmas results in olivine with relatively high $\mathrm{Ni}$ but low $\mathrm{Ca}$ and $\mathrm{Mn}$ concentrations compared to the melts formed by peridotite partial melting alone. The melts with highest $\mathrm{Ni} \times \mathrm{FeO} / \mathrm{MgO}$ and lowest $\mathrm{Mn} / \mathrm{FeO}$, as well as $\mathrm{Ca}$, should contain the highest contribution of reaction pyroxenite in accordance with the model of Sobolev et al. (2007). We therefore think that the presence of variable amounts of reaction pyroxenite in the source of the Canary shield stage magmas best explains the observed relationships between chemical compositions of olivine and whole rock $\mathrm{Sr}-\mathrm{Nd}-\mathrm{Pb}$ isotopic composition. The following arguments support this statement: 
(1) Strong variations of Ni concentrations (from 200 to $500 \mathrm{ppm}$ ) in the host lavas of nearly similar bulk rock composition (transitional basalts to picrobasalts with 13.5 to $16.1 \mathrm{wt} \%$ $\mathrm{MgO}$ ), whereas the El Hierro samples extend to the highest Ni concentrations for a given Fo content. The obtained error of $\mathrm{Ni}$ analyses at a concentration level above $100 \mathrm{ppm}$ is better than 5\% relative (Tables C.1 and C.2 in Gurenko et al., 2006). The observed Ni variations cannot be ascribed to analytical error. On the other hand, such a broad Ni range also cannot be explained by olivine fractionation alone assuming a certain $\mathrm{Ni}$ concentration in a common parental magma, as shown by Sobolev et al. $(2005,2007)$. We, thus, assume that the magmas inherited their original and varying $\mathrm{Ni}$ during partial melting of peridotite-pyroxenite lithologies, as shown by Sobolev et al. (2005, 2007).

(2) Strong variations of absolute $\mathrm{Ni}$ and $\mathrm{Mn}$, and their normalized concentrations (355-990 of $\mathrm{Ni} \times \mathrm{FeO} / \mathrm{MgO}$ and 90-120 of $\mathrm{Mn} / \mathrm{FeO}$ ) for any given Fo content (Figs 3 and S1, Online Supplementary information). Although highly variable oxygen redox conditions in the system could represent a reason for variable Fo content at constant $\mathrm{Ni}$ and $\mathrm{Mn}$ concentrations, the $\mathrm{Fe}^{2+} / \mathrm{Fe}^{3+}$ ratios in spinels give a narrow range in oxygen redox states ranging from FMQ to NNO during magma fractionation (Gurenko et al., 1996, 1998, 2006). Therefore, the effect of strongly varying redox conditions in the system can be ruled out.

(3) Similar to the large range in $\mathrm{Ni}$ and $\mathrm{Mn}$ concentrations, the large range of $\mathrm{Ca}$ concentrations (ca. 700 to $3000 \mathrm{ppm}$ ) and the absence of a clear correlation of Ca with Fo contents (Fig. S1, Online Supplementary information) could also be considered as evidence supporting the “pyroxenite" model (Herzberg, 2006a; Sobolev et al, 2007). As shown experimentally by Libourel (1999 and references therein), the concentration of $\mathrm{Ca}$ in olivine is controlled not only by Fo content but, to a large extent, by melt composition, whereas oxygen fugacity, temperature and pressure do not directly affect Ca partitioning. As most of the lavas, except those from El Hierro, are picrobasalts with rather limited variations of alkalis, we do not believe that shallow depth crystallization processes could affect $\mathrm{Ca}$ concentrations in olivine from Tenerife, La Gomera and La Palma lavas. We also emphasize that the relatively low Ca 
concentrations in El Hierro olivines are not related to the basanitic composition of the host magma. Calcium in olivine appears to be sensitive to the amount of alkalis in the coexisting melt (Libourel, 1999), so that olivine crystallized from more alkali-rich melts should be more Ca-rich. To the contrary, olivines from El Hierro basanites have the lowest Ca concentrations compared to those from less alkali-rich lavas from the other Canary Islands. Furthermore, one lava from the La Palma shield (sample LP48) approaches basanitic composition but does not show any significant difference in $\mathrm{Ca}$ in olivine, as compared to other samples from La Palma (Table 1). Finally, the concentrations of Ca in olivine correlate well with $\mathrm{Ni} \times \mathrm{FeO} / \mathrm{MgO}$ and $\mathrm{Mn} / \mathrm{FeO}$ ratios (not shown) suggesting that (a) the observed $\mathrm{Ca}$ range is unlikely to be due to shallow fractionation and (b) probably is related to the amount of pyroxenite component in the source, as was shown by Herzberg (2006a) and Sobolev et al. (2007).

An alternative explanation of the origin of high-Ni olivines was suggested by Wang and Gaetani (2008) based on experimental data on partitioning of Ni between olivine and siliceous eclogite partial melt. They demonstrated that $\mathrm{Ni}$ is more compatible in olivine crystallizing from siliceous melts ( $\mathrm{K}_{\mathrm{D}}$ for Ni being12-22) than in those of basaltic magmas. These authors have also shown that high Ni concentrations in some Hawaiian olivines (e.g., those from Koolau lavas) could be ascribed to higher $\mathrm{K}_{\mathrm{D}}(\mathrm{Ni})$ obtained experimentally in the melts with elevated $\mathrm{SiO}_{2}$. However, the experimental data by Wang and Gaetani (2008) fail to explain the coherent overall decrease of $\mathrm{Mn} / \mathrm{FeO}$ ratios in olivine with increasing $\mathrm{Ni} \times \mathrm{FeO} / \mathrm{MgO}$. The olivine-melt distribution coefficients of Fe and Mn obtained by Wang and Gaetani (2008) are very similar and both $\mathrm{K}_{\mathrm{D}}(\mathrm{Fe})$ and $\mathrm{K}_{\mathrm{D}}(\mathrm{Mn})$ lines show a sub-parallel increase with increasing NBO/T $(\mathrm{NBO} / \mathrm{T}$ - the degree of polymerization of a silicate melt expressed as a ratio of non-bridging oxygen per tetrahedrally coordinated cations; Mysen, 1983; see Fig. 7 in Wang and Gaetani, 2008), and thus the $K_{D}(F e) / K_{D}(M n)$ ratio remains nearly constant over the entire $\mathrm{NBO} / \mathrm{T}$ range. The reaction of eclogite partial melt with olivine from peridotite is, in contrast, very effective in changing the $\mathrm{Mn} / \mathrm{Fe}$ ratio. Olivine is the only major 
silicate phase in peridotite having a larger $K_{D}$ for Fe than for Mn (Humayun et al., 2004) and thus this reaction may cause a coupled increase of $\mathrm{Ni}$ with decrease of $\mathrm{Mn} / \mathrm{Fe}$ ratio in the melts. We therefore believe that the variations of $\mathrm{Ni}$ and $\mathrm{Mn}$ concentrations observed in olivine phenocrysts from the Canary Island shield stage magmas primarily resulted from varying peridotite to pyroxenite ratios in the magma source rather than from mixing and crystallization of a spectrum of silica-rich hybrid magmas as postulated in the model of Wang and Gaetani (2008). Moreover, we emphasize that the effect of preferential partitioning of $\mathrm{Ni}$ in olivine due to increasing $\mathrm{SiO}_{2}$ contents in equilibrium melt cannot explain the strongly varying and in part very high $\mathrm{Ni} \times \mathrm{FeO} / \mathrm{MgO}$ ratios observed in olivine phenocrysts from El Hierro silica-undersaturated basanite lavas.

\subsection{Source components involved in the Canary shield magmatism}

A large number of isotopic studies have been carried out on the Canary Islands and related seamounts to assess the mantle components involved in forming the Canarian magmas (Sun, 1980; Hoernle and Tilton, 1991; Hoernle et al., 1991; Cousens et al., 1990; Marcantonio et al., 1995; Thirlwall, 1997; Thirlwall et al., 1997; Hoernle, 1998; Widom et al., 1999; Simonsen et al., 2000; Geldmacher et al., 2001, 2005; Abratis et al., 2002; Lundstrom et al., 2003; Gurenko et al., 2006). These studies have identified three types of mantle components in the Canarian source, which can be broadly classified as HIMU-type (or LVC; Hoernle et al., 1995), DMM (MORB-source) and EM type components (e.g. Zindler and Hart, 1986). It should be noted, however, that the Canaries and many other ocean island basalts (OIBs) with intermediate ${ }^{206} \mathrm{~Pb} /{ }^{204} \mathrm{~Pb}$ isotopic compositions (greater than found in N-MORB), cannot be explained by simply mixing a "classical" HIMU end-member (St. Helena in the Atlantic and Mangaia/Tubuaii in the Pacific) with DMM, since these OIBs have low ${ }^{207} \mathrm{~Pb} /{ }^{204} \mathrm{~Pb}$ and plot beneath the NHRL rather than on a mixing trend between MORB (DMM) and end-member HIMU. Nevertheless, Thirlwall (1997) showed that recycled ocean crust with ages ranging from $0.5-2.0 \mathrm{Ga}$ and variable $\mu$ would form a complete continuum of "HIMU"-like compositions (characterized by more radiogenic ${ }^{206} \mathrm{~Pb} /{ }^{204} \mathrm{~Pb}$, slightly more radiogenic Sr and slightly less radiogenic or similar $\mathrm{Nd}$ and $\mathrm{Hf}$ isotope ratios compared to $\mathrm{N}-\mathrm{MORB}$ ). If the recycling age is 
$<1.8 \mathrm{Ga}$, these samples will also have low $\Delta 7 / 4$, plotting below the NHRL. Using combined $\mathrm{Pb}$ and Os isotopes, Widom et al. (1999) showed that the LVC endmember for the Canary Island volcanic rocks could be generated with a $25-40 \%$ contribution of $1.2 \mathrm{Ga}$ old recycled ocean crust, consistent with the model of Thirlwall (1997).

As is clear from isotope correlation diagrams of ${ }^{206} \mathrm{~Pb} /{ }^{204} \mathrm{~Pb}$ versus ${ }^{87} \mathrm{Sr} /{ }^{86} \mathrm{Sr},{ }^{143} \mathrm{Nd} /{ }^{144} \mathrm{Nd}$ and ${ }^{207} \mathrm{~Pb} /{ }^{204} \mathrm{~Pb}$ (Fig. 2) and ${ }^{208} \mathrm{~Pb} /{ }^{204} \mathrm{~Pb}$ (not shown) isotope ratios, only HIMU- and DMM-type components are required to explain the isotopic variations in the shield stage lavas of the westernmost Canary Islands. In particular, Tenerife, La Gomera and La Palma require varying amounts (and compositions) of a HIMU-type material with relatively radiogenic $\mathrm{Pb}\left({ }^{206} \mathrm{~Pb} /{ }^{204} \mathrm{~Pb}>\right.$ 20.0) and $\mathrm{Sr}$ and unradiogenic $\mathrm{Nd}$ with some admixture of a MORB-type component. El Hierro shield lavas, on the other hand, indicate the most extensive presence of the depleted, MORB-like signature (unradiogenic $\mathrm{Sr}$ and $\mathrm{Pb}$ but radiogenic $\mathrm{Nd}$ isotope ratios), with both components and the samples lying below the NHRLin Fig. 2c.

The HIMU-like component was called the low velocity component by Hoernle et al. (1995) because of its association with a sublithospheric low seismic velocity anomaly extending to depth. This component was interpreted to be a common plume-type component found beneath the Canary and Madiera Islands, the western Mediterranean and western Europe. Samples from Madeira (with ${ }^{87} \mathrm{Sr} /{ }^{86} \mathrm{Sr}=0.7026-0.7028$ and $\left.{ }^{143} \mathrm{Nd} /{ }^{144} \mathrm{Nd}=0.5131-0.5132\right)$ formed the isotopically depleted end of this array with samples from El Hierro being the most depleted from the Canary Islands. Samples from both islands are mafic basanites with enriched, HIMU-type incompatible element abundances. Whereas most studies of the Canary Islands interpreted the depleted component to be the depleted upper MORB-source mantle, Thirlwall (1997) demonstrated that isotopic arrays similar to that formed by the La Palma, La Gomera and Tenerife shield lavas could be generated by young $(<1 \mathrm{Ga})$ recycled ocean crust and therefore involvement of a depleted asthenospheric component is not necessarily required. Geldmacher and Hoernle (2000) proposed that the isotopically depleted but incompatible-element enriched Madeira basanites were derived from young (Paleozoic) recycled lower oceanic crust in the form of eclogite contained within the plume. In an Os isotope study of the 
Canary and Madeira Islands, Widom et al. (1999) showed that the LVC end-member has ${ }^{187}$ Os/ ${ }^{188}$ Os between $0.14-0.15$ and modeled the $\mathrm{Pb}$ and $\mathrm{Os}$ isotope data as a mixture of c. $25-35 \%$ recycled 1.2 Ga old oceanic crust with mantle peridotite. The depleted Madeira basanites were modeled as representing a mixture of $\sim 70 \%$ depleted component $(50 \%$ Paleozoic recycled ocean crust as eclogite and 50\% depleted upper mantle peridotite) and $\sim 30 \%$ LVC, whereas the most depleted Canary lava required a mixture of $\sim 50 \%$ depleted component and $\sim 50 \%$ LVC. Therefore the most isotopically depleted Madeira basanites were interpreted as being derived from a source containing $\sim 45 \%(\sim 10 \% 1.2 \mathrm{Ga}$ and $\sim 35 \% 0.5 \mathrm{Ga})$ and the depleted Canary sample $\sim 40 \%(\sim 15 \% 1.2 \mathrm{Ga}$ and $\sim 25 \% 0.5 \mathrm{Ga}$ ) recycled ocean crust (eclogite).

\subsection{Isotopic composition of peridotite and pyroxenite constituents of the Canary plume}

We apply the parameterization of Sobolev et al. (2008) utilizing normalized Ni and Mn contents in olivine phenocrysts to obtain relative proportions of pyroxenite-derived melt. Each lava specimen is considered as an individual portion of a hybrid magma that originated by mixing of peridotitic and pyroxenitic melt fractions. The equation used is:

$$
X_{p x}=6.705 \mathrm{E}-04 \times[\mathrm{Ni} \times \mathrm{FeO} / \mathrm{MgO}]-1.332 \mathrm{E}-02 \times[\mathrm{Mn} / \mathrm{FeO}]+1.5215
$$

where $X_{p x}=$ weight fraction of pyroxenite-derived melt; Ni and Mn are element concentrations given in ppm, $\mathrm{FeO}$ and $\mathrm{MgO}$ are given in wt.\%. The constant coefficients in Eq. 1 differ from those given in Sobolev et al. (2008), being modified after rearrangement in one, common equation and to account for $\mathrm{Ni} \times \mathrm{FeO} / \mathrm{MgO}$ and $\mathrm{Mn} / \mathrm{FeO}$ variables used in the present work. Using linear regressions obtained for each isotopic ratio allows quantitative assessment of the end-member compositions: peridotitic mantle with $X_{p x}=0$ and reaction pyroxenite having $X_{p x}=1$. The calculated amounts of the assumed pyroxenite melt are given in Table 1.

Next, we combined calculated proportions of pyroxenite-derived melt for each individual lava with bulk rock ${ }^{86} \mathrm{Sr} /{ }^{87} \mathrm{Sr},{ }^{143} \mathrm{Nd} /{ }^{144} \mathrm{Nd},{ }^{206} \mathrm{~Pb} /{ }^{204} \mathrm{~Pb},{ }^{207} \mathrm{~Pb} /{ }^{204} \mathrm{~Pb}$ and ${ }^{208} \mathrm{~Pb} /{ }^{204} \mathrm{~Pb}$ isotopic ratios. Tenerife, La Gomera, La Palma and El Hierro lavas form good correlations between their bulk rock isotopic ratios and inferred $X_{p x}$ values (Fig. 5), which were used for determination of isotopic 
compositions of peridotite and pyroxenite end-members. It is to be noted that the lavas with the most radiogenic $\mathrm{Pb}$ isotopic composition are formed through a mixture of $\sim 70 \%$ peridotite and $\sim 30 \%$ reaction pyroxenite (derived from eclogite), agreeing astoundingly well with the proportion of recycled oceanic crust or eclogite (25-35\%) estimated from the Os and $\mathrm{Pb}$ isotopic data (Widom et al., 1999). The depleted Hierro basanites can be explained as being derived from a mixture of $\sim 25 \%$ peridotite and $\sim 75 \%$ pyroxenite components, requiring probably somewhat more pyroxenite in the source than calculated from the $\mathrm{Os}$ and $\mathrm{Pb}$ isotope data $(\sim 45 \%)$. We note however that the amount of recycled crust in the source of the most depleted Canarian lavas based on the Os and $\mathrm{Pb}$ isotope data is critically dependent on the assumed age and composition (daughter element concentrations and parent/daughter and initial isotopic ratios) of the recycled oceanic crust. On the other hand, the amount of pyroxenite-derived fracion in the hybrid melt may not always be equal to the proportion of recycled eclogite/pyroxenite in the source because it strongly depends on the degree of partial melting of pyroxenite relative to peridotite.

Our results have important implications for the nature and possibly origin of the HIMU component in the Canary and possibly other plumes. The HIMU signature in OIB magmas is commonly attributed to the recycling of deeply subducted ancient oceanic crust in the form of eclogite through mantle plumes originating at the core-mantle boundary or D" layer (Morgan, 1971; Hofmann and White, 1982; Kellog et al., 1999; Albarède and van der Hilst, 1999). Indeed, the roots of the Canary plume can be traced to the core-mantle boundary (Goes et al., 1999; Montelli et al., 2004, 2006). The olivine chemistry, however, indicates that the HIMU-type component in the Canaries is not necessarily limited to the physical form of eclogite and/or reaction pyroxenite but can also be peridotite. A similar conclusion was reached independently by Herzberg (2006b), who has shown that HIMU-type lavas from the Cook-Austral Islands melted from a peridotite source, since they contain low $\mathrm{Ni}$ and high $\mathrm{Ca}$ concentrations. Olivines crystallized from such magmas would also be expected to have low $\mathrm{Ni}$ and high $\mathrm{Ca}$ concentrations. Therefore, if the HIMU component is indeed derived from old (ca. 1.2 Ga; Widom et al., 1999) recycled oceanic crust 
(eclogite), then it must have been stirred into or reacted with ambient peridotitic mantle in the Canary source so that there is no significant eclogite left to create olivine free reaction pyroxenite.

Alternatively, our results could provide support for "peridotite-based" models that have been proposed to explain the origin of the HIMU component. Halliday et al. (1995), for example, have proposed that the HIMU component could be derived through the metasomatism of the oceanic lithospheric mantle at about the time of formation of the lithosphere by small degree partial melts produced in equilibrium with a combination of residual upper mantle major silicate phases together with minor accessory phases such amphibole, sulfide and phlogopite. Recycling of such lithospheric mantle could therefore also potentially explain the HIMU signature seen in the Canary basalts. Oxygen isotope studies of the Canary basalts, however, could help distinguish between mantle $\left(\delta^{18} \mathrm{O}\right.$ of 5.0-5.2 in olivine) and crustal ( $\delta^{18} \mathrm{O}$ lower or higher than the mantle range) origins for the HIMUtype component in the Canary basalts. Olivines from Tenerife and La Gomera shield lavas, in part those studied here, produced a range in $\delta^{18} \mathrm{O}$ of 4.3-5.8 $( \pm 0.3 \%$, $2 \delta \mathrm{SD}$; Gurenko et al., 2006 and unpublished data). Based on correlations with radiogenic isotope ratios, this range was interpreted to be a characteristic of the mantle source. Therefore these data provide evidence for the involvement of recycled oceanic crust in the HIMU-type source, although the additional presence of metasomatized suboceanic lithospheric mantle cannot be ruled out.

The inferred isotopic composition of the peridotitic end-member is very similar to that of LVC component proposed by Hoernle et al. (1995) and therefore our results could be applicable to the source of intraplate volcanism in not only the eastern North Atlantic but also throughout the western Mediterranean and Europe. The composition of the peridotitic Canarian component $\left({ }^{87} \mathrm{Sr} /{ }^{86} \mathrm{Sr}=0.70324 \pm 0.00005,{ }^{143} \mathrm{Nd} /{ }^{144} \mathrm{Nd}=0.51283 \pm 0.00002,{ }^{206} \mathrm{~Pb} /{ }^{204} \mathrm{~Pb}=20.45 \pm 0.09\right.$, ${ }^{207} \mathrm{~Pb} /{ }^{204} \mathrm{~Pb}=15.68 \pm 0.01,{ }^{208} \mathrm{~Pb} /{ }^{204} \mathrm{~Pb}=40.2 \pm 0.1$; Table 2, Fig. 5), however, has somewhat higher ${ }^{206} \mathrm{~Pb} /{ }^{204} \mathrm{~Pb}$ and ${ }^{208} \mathrm{~Pb} /{ }^{204} \mathrm{~Pb}$ ratios and thus is more enriched in the hypothetical HIMU-type mantle component than previously predicated for the $\operatorname{LVC}\left({ }^{87} \mathrm{Sr} /{ }^{86} \mathrm{Sr}=0.7030-0.7034,{ }^{143} \mathrm{Nd} /{ }^{144} \mathrm{Nd}=\right.$ $\left.0.5128-0.5129,{ }^{206} \mathrm{~Pb} /{ }^{204} \mathrm{~Pb}=19.9-20.1,{ }^{207} \mathrm{~Pb} /{ }^{204} \mathrm{~Pb}=15.62-15.68,{ }^{208} \mathrm{~Pb} /{ }^{204} \mathrm{~Pb}=39.6-39.9\right)$ based on the convergence of the isotopic arrays for volcanism in the eastern North Altantic and the western 
Mediterranean and Europe. It should be noted, however, that the convergence of the data arrays only provide a minimum possible $\mathrm{Pb}$ isotopic composition for the common component and do not exclude a more radiogenic $\mathrm{Pb}$ isotopic composition. In conclusion, the LVC component could be peridotitic and have higher ${ }^{206} \mathrm{~Pb} /{ }^{204} \mathrm{~Pb}(\sim 20.45)$ and ${ }^{208} \mathrm{~Pb} /{ }^{204} \mathrm{~Pb}(40.2)$ than previously proposed. If so, lavas have not yet been found in the eastern North Atlantic, Western Europe and the western Mediterranean that have directly sampled this end-member.

The isotopic composition of olivine-free pyroxenite required for the origin of lavas erupted on the western Canary Islands was defined using the same regression equation (1). The pyroxenite component exhibits a more depleted composition - less radiogenic $\mathrm{Sr}\left({ }^{87} \mathrm{Sr} /{ }^{86} \mathrm{Sr}=0.70286 \pm\right.$ $0.00005)$ and $\mathrm{Pb}\left({ }^{206} \mathrm{~Pb} /{ }^{204} \mathrm{~Pb}=19.1 \pm 0.3,{ }^{207} \mathrm{~Pb} /{ }^{204} \mathrm{~Pb}=15.49-15.54 \pm 0.01,{ }^{208} \mathrm{~Pb} /{ }^{204} \mathrm{~Pb}=37.8-38.6\right.$ $\pm 0.3)$ and more radiogenic $\mathrm{Nd}\left({ }^{143} \mathrm{Nd} /{ }^{144} \mathrm{Nd}=0.51300-0.51304 \pm 0.00002\right)$ isotopic ratios - than the peridotite component and resembles MORB in composition (Table 2, Fig. 5). It should be noted that the composition of the pyroxenitic component obtained during this study has more radiogenic $\mathrm{Sr}$ and $\mathrm{Pb}$ and less radiogenic $\mathrm{Nd}$ isotope ratios than the most depleted sample from Madeira (with ${ }^{87} \mathrm{Sr} /{ }^{86} \mathrm{Sr}$ $=0.70266,{ }^{206} \mathrm{~Pb} /{ }^{204} \mathrm{~Pb}=18.7$ and ${ }^{143} \mathrm{Nd} /{ }^{144} \mathrm{Nd}=0.51317$; Geldmacher and Hoernle, 2000), indicating that the depleted end-member in the Canaries has a distinct composition from the depleted end-member on Madeira. This result is particularly interesting considering the homogeneity in the HIMU-type (or LVC) component sampled by intraplate volcanism throughout the eastern North Atlantic and the western Mediterranean and Europe, presumably derived from a well-mixed reservoir located at the core-mantle boundary, containing ancient recycled oceanic crust with an average age of $\sim 1.2 \mathrm{Ga}$ (Widom et al., 1999). On the other hand, the depleted, young $(<1$ Ga; Widom et al., 1999; Geldmacher and Hoernle, 2000) eclogitic/pyroxenitic components appear to vary in age and composition regionally and therefore are most likely picked up by the plume during its ascent, possibly from the slab graveyard at $660 \mathrm{~km}$ (Goes et al., 1999) or are located within the shallow mantle (either lithosphere or asthenosphere) beneath the islands. Greater amounts of the younger component in the El Hierro lavas is consistent with entrainment of this component on the 
margins of the Canary plume, whose center is likely to be located somewhere beneath the other three western islands (Tenerife, La Gomera and La Palma; Fig. 1).

\section{Conclusions}

1. Nickel, $\mathrm{Mn}$ and $\mathrm{Ca}$ concentrations in olivine phenocrysts appear to be powerful tracers of deep mantle processes. We observe clear relationships of $\mathrm{Ni}$ and $\mathrm{Mn}$ concentrations normalized to $\mathrm{FeO}$ and $\mathrm{MgO}$ and absolute $\mathrm{Ca}$ concentrations in olivine with bulk rock Sr$\mathrm{Nd}-\mathrm{Pb}$ radiogenic isotope ratios.

2. At least two physically and chemically distinct components were involved in the partial melting to form the western Canary Islands: the first is peridotite with an isotopic composition similar to but with more radiogenic $\mathrm{Pb}$ than that of the low-velocity plume component proposed by Hoernle et al. (1995) and the second is pyroxenite/eclogite with a depleted, MORB-type composition.

3. This study demonstrates that the physical state of a recycled component involved in ocean island magmatism is not necessarily limited to the form of eclogite and/or pyroxenite but can also be present as peridotite only. The data presented in this study combined with published data from the Canary Islands shows that the HIMU-like (i.e., recycled, crustal) component was completely stirred back into the peridotitic mantle, which may be the general case for recycled crustal material with ages $>1 \mathrm{Ga}$.

4. We ascribe the origin of the depleted pyroxenite component to the presence of young $(<1$ $\mathrm{Ga}$ ) recycled oceanic crust in the Canary Island source.

5. We propose that short (less than $\sim 1 \mathrm{Ga}$ ) recycling times for ocean crust can preserve both its eclogitic nature in the mantle source and the MORB-like isotopic composition of the longlived radiogenic isotope systems (e.g. $\mathrm{Sr}, \mathrm{Nd}, \mathrm{Pb}$ and $\mathrm{Hf}$ ), whereas longer recycling times $(>1 \mathrm{Ga})$ can result in the physical disappearance of the eclogite in the peridotitic mantle while allowing the long-lived radiogenic isotope systems to evolve to more radiogenic $\mathrm{Pb}$ (HIMU-like) compositions. A common characteristic of melts from both young and old 
recycled oceanic crust are HIMU-like trace element characteristics (e.g. on multi-element diagrams). Finally we suggest that older recycled components may be stored at the coremantle boundary (D"), whereas younger recycled components may largely reside within the upper mantle.

Acknowledgements - We thank $\mathrm{S}$. Hauff for assistance in carrying out $\mathrm{Sr}-\mathrm{Nd}-\mathrm{Pb}$ isotope analyses. The Museum of Natural History, Washington DC kindly provided us with standards for electron microprobe analysis. Fruitful discussions with Stan Hart, Nobu Shimizu, Alberto Saal and other participants of the WHOI Geochemical Seminar are very much appreciated. Formal reviews by Claude Herzberg and one anonymous referee helped us to improve the manuscript. Editorial handling by Richard Carlson is gratefully acknowledged. This work was supported by Wolfgang Paul Award, Alexander von Humboldt Foundation, to AVS, the Max Planck Society, DFG grants SCHM 250/64 and 82-1, HA3097/2 to HUS, KH and FH, NSF Grant EAR-9105113 to KH, Russian Basic Research Foundation and Russian Academy of Sciences. 


\section{References}

Abdel-Monem, A., Watkins, N.D., Gast, P.W., 1971. Potassium-argon ages, volcanic stratigraphy, and geomagnetic polarity history of the Canary Islands: Lanzarote, Fuerteventura, Gran Canaria, and La Gomera. Amer. J. Sci. 271, 490-521.

Abdel-Monem, A., Watkins, N.D., Gast, P.W., 1972. Potassium-argon ages, volcanic stratigraphy, and geomagnetic polarity history of the Canary Islands: Tenerife, La Palma and Hierro. Amer. J. Sci. 272, 805-825.

Abratis, M., Schmincke, H.-U., Hansteen, T.H., 2002. Composition and evolution of submarine volcanic rocks from the central and western Canary Islands. Int. J. Earth Sci. 91, 562-582.

Albarède, F., van der Hilst, R.D., 1999. New mantle convection model may reconcile conflicting evidence. EOS 80, 537-539.

Allègre, C.J., Turcotte, D.L., 1986. Implications of a two-component marble-cake mantle. Nature $323,123-127$.

Beattie, P., Ford, C., Russell, D., 1991. Partition coefficients for olivine-melt and orthopyroxenemelt systems. Contrib. Mineral. Petrol. 109, 212-224.

Cousens, B.L., Spera, F.J., Tilton, G.R., 1990. Isotopic patterns in silicic ignimbrites and lava flows of the Mogan and lower Fataga Formations, Gran Canaria, Canary Islands: temporal changes in mantle source composition. Earth Planet. Sci. Lett. 96, 319-335.

Doucelance, R., Escrig, S., Moreira, M., Gariepy, C., Kurz M.D., 2003. Pb-Sr-He isotope and trace element geochemistry of the Cape Verde Archipelago, Geochim. Cosmochim. Acta 67, 37173733.

Escrig, S., Doucelance, R., Moreira, M., Allegre C.J., 2005. Os isotope systematics in Fogo Island: Evidence for lower continental crust fragments under the Cape Verde Southern Islands. Chem. Geol. 219, 93-113.

Fúster, J.M, Araña, V., Brändle, J.L., Navarro, J.M., Alonso, U., Aparicio, A., 1968. Tenerife. In: Geologa y Volcanologa de las Islas Canarias, Volcanol., Inst. Lucas Mallada, Madrid, Int. Symp., Spec. Publ., 218 p.

Geldmacher, J., Hoernle, K., 2000. The 72 Ma geochemical evolution of the Madeira hotspot (eastern North Atlantic): recycling of Palaeozoic ( $\leq 500 \mathrm{Ma})$ basaltic and gabbroic crust. Earth 
Planet. Sci. Lett. 183, 73-92 (Corrigendum in Geldmacher, J., Hoernle, K., 2001. Earth Planet. Sci. Lett. 186, 333).

Geldmacher, J., Hoernle, K., van den Bogaard, P., Zankl, G., Garbe-Schönberg, D., 2001. Earlier history of the 70-Ma-old Canary hotspot based on the temporal and geochemical evolution of the Selvagen Archipelago and neighboring seamounts in the eastern North Atlantic. J. Volcanol. Geotherm. Res. 111, 55-87.

Geldmacher, J., Hoernle, K., van den Bogaard, P., Duggen, S., Werner, R., 2005. New ${ }^{40} \mathrm{Ar} /{ }^{39} \mathrm{Ar}$ age and geochemical data from seamounts in the Canary and Madeira volcanic province: Support for the mantle plume hypothesis. Earth Planet. Sci. Lett. 237, 85-101.

Geldmacher, J., Hoernle, K., Klügel, A., Bogaard, P.v.d., Bindeman, I., 2008). Geochemistry of a new enriched mantle type locality in the northern hemisphere: Implications for the origin of the EM-I source. Earth Planet. Sci. Lett. 265, 167-182.

Gerlach, D.C., Cliff, R.A., Davies, G.R., Norry, M.J., Hodgson, N.R., 1988. Magma sources of the Cape Verde archipelago: isotopic and trace element constraints. Geochim. Cosmochim. Acta $52,2979-2993$.

Guillou, H., Carracedo, J.C., Torrado, F.P., Badiola, E.R., 1996. K-Ar ages and magnetic stratigraphy of a hotspot-induced, fast grown oceanic island: El Hierro, Canary Islands. J. Volcanol. Geotherm. Res. 73, 141-155.

Goes, S., Spakman, W., Bijwaard, H., 1999. A lower mantle source for Central European volcanism Science 268, 1928-1931.

Gurenko, A.A., Hansteen, T.H., Schmincke, H.-U., 1996. Evolution of parental magmas of Miocene shield basalts of Gran Canaria (Canary Islands): constraints from crystal, melt and fluid inclusions in minerals. Contrib. Mineral. Petrol. 124, 422-435.

Gurenko, A.A., Hansteen, T.H., Schmincke, H.-U., 1998. Melt, crystal, and fluid inclusions in olivine and clinopyroxene phenocrysts from the submarine shield stage hyaloclastites of Gran Canaria, Sites 953 and 956. In: Weaver, P.P.E., Schmincke, H.-U., Firth, J.V., Duffield, W. (Eds.), Proceedings of the Ocean Drilling Program, Scientific Results 157, pp. 375-401. College Station, TX (Ocean Drilling Program).

Gurenko, A.A., Hoernle, K.A., Hauff, F., Schmincke, H.-U., Han, D., Miura, Y.N., Kaneoka, I., 2006. Major, trace element and Nd-Sr-Pb-O-He-Ar isotope signatures of shield stage lavas from 
the central and western Canary Islands: Insights into mantle and crustal processes. Chem. Geol. $233,75-112$.

Halliday, A.N., Lee, D.-C., Tommasini, S., Davies, G.R., Paslick, C.R., Fitton, J.G., James, D.E., 1995. Incompatible trace elements in OIB and MORB and source enrichment in the sub-oceanic mantle. Earth Planet. Sci. Lett. 133, 379-395.

Hart, S.R., 1984. A large-scale isotope anomaly in the Southern Hemisphere mantle. Nature 309, 753-757.

Hart, S.R., Davis, K.E., 1978. Nickel partitioning between olivine and silicate melt. Earth Planet. Sci. Lett. 40, 203-219.

Herzberg, C., 2006a. Petrology and thermal structure of the Hawaiian plume from Mauna Kea volcano. Nature 444, 605-609.

Herzberg, C., 2006b. Distribution and size of pyroxenite bodies in the mantle. Eos Trans. AGU, 87(52), Fall Meet. Suppl., Abstract U12A-04.

Hoernle, K., 1998. Geochemistry of Jurassic oceanic crust beneath Gran Canaria (Canary Islands): implications for crustal recycling and assimilation. J. Petrol. 39, 859-880.

Hoernle, K., Tilton, G.R., 1991. Sr-Nd-Pb isotope data for Fuerteventura (Canary Islands) basal complex and subaerial volcanics: application to magma genesis and evolution. Schweiz. Min. Petrol. Mitt. 71, 5-21.

Hoernle, K., Schmincke, H.-U., 1993. The petrology of the tholeiites through melilite nephelinites on Gran Canaria, Canary Islands: Crystal fractionation, accumulation, and depths of melting. J. Petrol. 34, 573-597.

Hoernle, K., Tilton, G., Schmincke, H.-U., 1991. Sr-Nd-Pb isotopic evolution of Gran Canaria: evidence for shallow enriched mantle beneath the Canary Islands. Earth Planet. Sci. Lett. 106, 44-63.

Hoernle, K., Zhang, Y.-S., Graham, D., 1995. Seismic and geochemical evidence for large-scale mantle upwelling beneath the eastern Atlantic and western and central Europe. Nature 374, 3439.

Hoernle, K., Tilton, G., Le Bas, M.J., Duggen, S., Garbe-Schönberg, D., 2002. Geochemistry of oceanic carbonatites compared with continental carbonatites: mantle recycling of oceanic crustal carbonate. Contrib. Mineral. Petrol. 142, 520-542. 
Hofmann, A.W., 2003. Sampling mantle heterogeneity through oceanic basalts: Isotopes and trace elements. In: Holland, H.D., Turekian, K.K. (Eds.), Treatise on Geochemistry, vol. 2, Elsevier, 61-101.

Hofmann, A.W., White, W.M., 1982. Mantle plumes from ancient oceanic crust. Earth Planet. Sci. Lett. 57, 421-436.

Hofmann, A.W., Jochum, K.P., Seufert, M., White, W.M., 1986. Nb and Pb in oceanic basalts: new constraints on mantle evolution. Earth Planet. Sci. Lett. 79, 33-45.

Humayun, M., Qin, L., Norman, M.D., 2004. Geochemical evidence for excess iron in the mantle beneath Hawaii. Science 306, 91-94.

Ibarrola, E., 1970. Variation trends in basaltic rocks of the Canary islands. Bull. Volcanol. 33, 729777.

Kellogg, L.H., Hager, B.H., van der Hilst, R.D., 1999. Compositional stratification in the deep mantle. Science 283, 1881-1884.

Libourel, G., 1999. Systematics of calcium partitioning between olivine and silicate melt: implications for melt structure and calcium content of magmatic olivines. Contrib. Mineral. Petrol. 136, 63-80.

Lundstrom, C.C., Hoernle, K., Gill, J., 2003. U-series disequilibria in volcanic rocks from the Canary Islands: Plume versus lithospheric melting. Geochim. Cosmochim. Acta 67, 4153-4177. Marcantonio, F., Zindler, A., Elliott, T., Staudigel, H., 1995. Os isotope systematics of La Palma, Canary Islands; evidence foe recycled crust in the mantle source of HIMU ocean islands. Earth Planet. Sci. Lett. 133, 397-410.

Montelli, R., Nolet, G., Dahlen, F.A., Masters, G., Engdahl, E.R., Hung, S.-H., 2004. Finitefrequency tomography reveals a variety of plumes in the mantle. Science 303, 338-343.

Montelli, R., Nolet, G., Dahlen, F.A., Masters, G., 2006. A catalogue of deep mantle plumes: New results from finite-frequency tomography. Geochem. Geophys. Geosyst. 7, DOI 10.1029/2006GC001248.

Morgan, J.W., 1971. Convection plumes in the lower mantle. Nature 230, 42-43.

Mysen, B., 1983. The structure of silicate melts. Ann. Rev. Earth Planet. Sci. 11, 75-97. 
Schmincke, H.-U., 1982. Volcanic and chemical evolution of the Canary Islands. In: von Rad, U., Hinz, K., Sarnthein, M., Seibold, E. (Eds.), Geology of the Northwest African Continental Margin, Springer, pp. 273-306.

Schmincke, H.-U., Sumita, M., 1998. Volcanic evolution of Gran Canaria reconstructed from apron sediments: Synthesis of VICAP project drilling (ODP Leg 157). In: Weaver, P.P.E., Schmincke, H.-U., Firth, J.V., Duffield, W. (Eds.), Proceedings of the Ocean Drilling Program, Scientific Results 157, pp. 443-469. College Station, TX (Ocean Drilling Program).

Simonsen, S.L., Neumann, E.-R., Seim, K., 2000. Sr-Nd-Pb isotope and trace-element geochemistry evidence for a young HIMU source and assimilation at Tenerife (Canary Island). J. Volcanol. Geotherm. Res. 103, 299-312.

Sobolev, A.V., Hofmann, A.W., Sobolev, S.V., Nikogosian, I.K., 2005. An olivine-free mantle source of Hawaiian shield basalts. Nature 434, 590-597.

Sobolev, A.V., Hofmann, A.W., Kuzmin, D.V., Yaxley, G.M., Arndt, N.T., Chung, S.-L., Danyushevsky, L.V., Elliott, T., Frey, F.A., Garcia, M.O., Gurenko, A.A., Kamenetsky, V.S., Kerr, A.C., Krivolutskaya, N.A., Matvienkov, V.V., Nikogosian, I.K., Rocholl, A., Sigurdsson, I.A., Sushchevskaya, N.M., Teklay, M., 2007. The amount of recycled crust in sources of mantle-derived melts. Science 316, 412-417, published online 28 March 2007, doi:10.1126/Science. 1138113.

Sobolev, A.V., Hofmann, A.W., Brügmann, B., Batanova, V.G., Kuzmin, D.V., 2008. A quantitative link between recycling and osmium isotopes. Science 321, 536.

Sun, S.S., 1980. Lead isotopic study of young volcanic rocks from mid-ocean ridges, ocean islands and island arcs. In: Bailey, K. Tarney, J., Dunham, K. (Eds.), The Evidence for Chemical Heterogeneity in the Earth's Mantle, Royal Society of London, pp. 409-445.

Taylor, J.R., 1982. An Introduction to Error Analysis. Oxford Univ. Press, Oxford.

Thirlwall, M.F., 1997. Pb isotopic and elemental evidence for OIB derivation from young HIMU mantle. Chem. Geol. 139, 51-74.

Thirlwall, M.F., Jenkins, C., Vroon, P.Z., Mattey, D.P., 1997. Crustal interaction during construction of oceanic islands: $\mathrm{Pb}-\mathrm{Sr}-\mathrm{Nd}-\mathrm{O}$ isotope geochemistry of the shield basalts of Gran Canaria, Canary Islands. Chem. Geol. 135, 233-262. 
Wang, C., Gaetani, G.A., 2008. Partitioning of Ni between olivine and siliceous eclogite partial melt: experimental constraints on the mantle source of Hawaiian basalts. Contrib. Mineral. Petrol. 156, 661-678.

White, W.M., 1985. Sources of oceanic basalts: radiogenic isotopic evidence. Geology 13, 115-118.

White, W. M., Hofmann, A. W., 1982. Sr and Nd isotope geochemistry of oceanic basalts and mantle evolution. Nature 296, 821-825.

Widom, E., Hoernle, K.A., Shirey, S.B., Schmincke, H.-U., 1999. Os isotope systematics in the Canary Islands and Madeira: Lithospheric contamination and mantle plume signatures. J. Petrol. 40, 297-314.

Zindler, A., Hart, S., 1986. Chemical geodynamics. Ann. Rev. Earth Planet. Sci. 14, 493-571.

Zindler, A., Jagoutz, E., Goldstein, S., 1982. Nd, $\mathrm{Sr}$ and $\mathrm{Pb}$ isotopic systematics in a threecomponent mantle: a new perspective. Nature 298, 519-523. 


\section{Figure captions}

Fig. 1. The map of the eastern North Atlantic highlights the four western Canary Islands (Tenerife, La Gomera, La Palma and El Hierro). The location of these islands on oceanic lithosphere well away from possible influence of the African continental lithosphere and the thick continental rise sedimentary pile was one of the main reasons for selecting their shield stages of volcanism for this study. The numbers in parenthesis below the island/seamount names refer to the oldest ages in million years obtained for shield stage volcanism from these islands/seamounts (see Geldmacher et al., 2005).

Fig. 2. Whole rock isotopic compositions of the studied Canarian shield stage lavas on ${ }^{206} \mathrm{~Pb} /{ }^{204} \mathrm{~Pb}$ versus (A) ${ }^{87} \mathrm{Sr} /{ }^{86} \mathrm{Sr}$ diagram, displaying a crude positive correlation, (B) ${ }^{143} \mathrm{Nd} /{ }^{144} \mathrm{Nd}$ diagram, forming a negative correlation, and $(\mathrm{C}){ }^{207} \mathrm{~Pb} /{ }^{204} \mathrm{~Pb}$ diagram, forming a positive correlation. The $\mathrm{Sr}-\mathrm{Nd}-\mathrm{Pb}$ isotope data can be explained largely by binary mixing of a LVC (enriched, HIMUtype component) with a depleted (MORB or DMM-type) component (Hoernle et al., 1995). The data for Tenerife suggests that there may be minor heterogeneity in the HIMU-type source. The HIMU-type peridotitic end-member (Peridotite) and the depleted MORB-type pyroxenitic endmember (Pyroxenite) obtained during present study are from Fig. 5. Mixing between these endmembers represents the best fit linear regressions for the data as well. The compositions of DMM, HIMU, EM1 and EM2 mantle components are taken from Zindler and Hart (1986); MORB from the literature; LVC - low-velocity component ubiquitous sublithospheric component beneath the eastern Atlantic, Europe and the western Mediterranean from Hoernle et al. (1995).

Fig. 3. Compositions of the most Mg-rich olivine phenocrysts from the studied Canarian shield stage lavas. Concentrations of $\mathrm{Ni}$ and $\mathrm{Mn}$ (in ppm) normalized to $\mathrm{MgO}$ and $\mathrm{FeO}$ (in wt.\%) and shown on plots versus Fo contents (mol. \%) i.e., (A) $\mathrm{Ni} \times \mathrm{FeO} / \mathrm{MgO}$ vs. Fo and (B) $\mathrm{Mn} / \mathrm{FeO}$ vs Fo demonstrate the wide ranges of $\mathrm{Ni}$ and $\mathrm{Mn}$ at a given Fo despite elimination of magma fractionation on Ol composition. SCOL = San Carlos olivine USNM 111312/444 was multiply analyzed as unknown $(\mathrm{N}=125)$ together with the samples of interest (three to five points after every 30-50 analyses of unknown samples) and represents the real analytical error. 
Fig. 4. Relationships between ${ }^{87} \mathrm{Sr} /{ }^{86} \mathrm{Sr},{ }^{143} \mathrm{Nd} /{ }^{144} \mathrm{Nd}$ and ${ }^{206} \mathrm{~Pb} /{ }^{204} \mathrm{~Pb}$ isotopic ratios of the Canary Islands shield stage lavas and average $(\mathrm{A}, \mathrm{D}, \mathrm{G}) \mathrm{Ni} \times \mathrm{FeO} / \mathrm{MgO}$ and $(\mathrm{B}, \mathrm{E}, \mathrm{H}) \mathrm{Mn} / \mathrm{FeO}$ ratios, and $(\mathrm{C}, \mathrm{F}, \mathrm{I}) \mathrm{Ca}$ concentrations calculated in olivine phenocrysts with the highest three Fonumbers for each sample. $\mathrm{Ni} \times \mathrm{FeO} / \mathrm{MgO}$ ratios of olivine correlate negatively with $\mathrm{Sr}$ and $\mathrm{Pb}$ isotope ratios of whole-rock lavas and positively with $\mathrm{Nd}$ isotope ratios, whereas $\mathrm{Mn} / \mathrm{FeO}$ ratios and Ca concentrations show the opposite trends.

Fig. 5. Sr-Nd-Pb isotopic composition of peridotite and pyroxenite components of the Canary plume. The linear regressions point to an enriched, HIMU-type peridotitic end-member with relatively radiogenic $\mathrm{Pb}$ and $\mathrm{Sr}$ and unradiogenic $\mathrm{Nd}$ and a depleted, MORB-type pyroxenitic end-member with relatively unradiogenic $\mathrm{Pb}$ and $\mathrm{Sr}$ but radiogenic $\mathrm{Nd}$ isotopic composition. The linear regressions $\left(y=A x X_{p x}+B\right)$ presented in the panels relate the fraction of pyroxenite component $\left(X_{p x}\right)$ calculated using the parameterization of Sobolev et al. (2008; see text) and the corresponding isotopic ratios with $R^{2}=$ squared coefficient of linear correlation. 


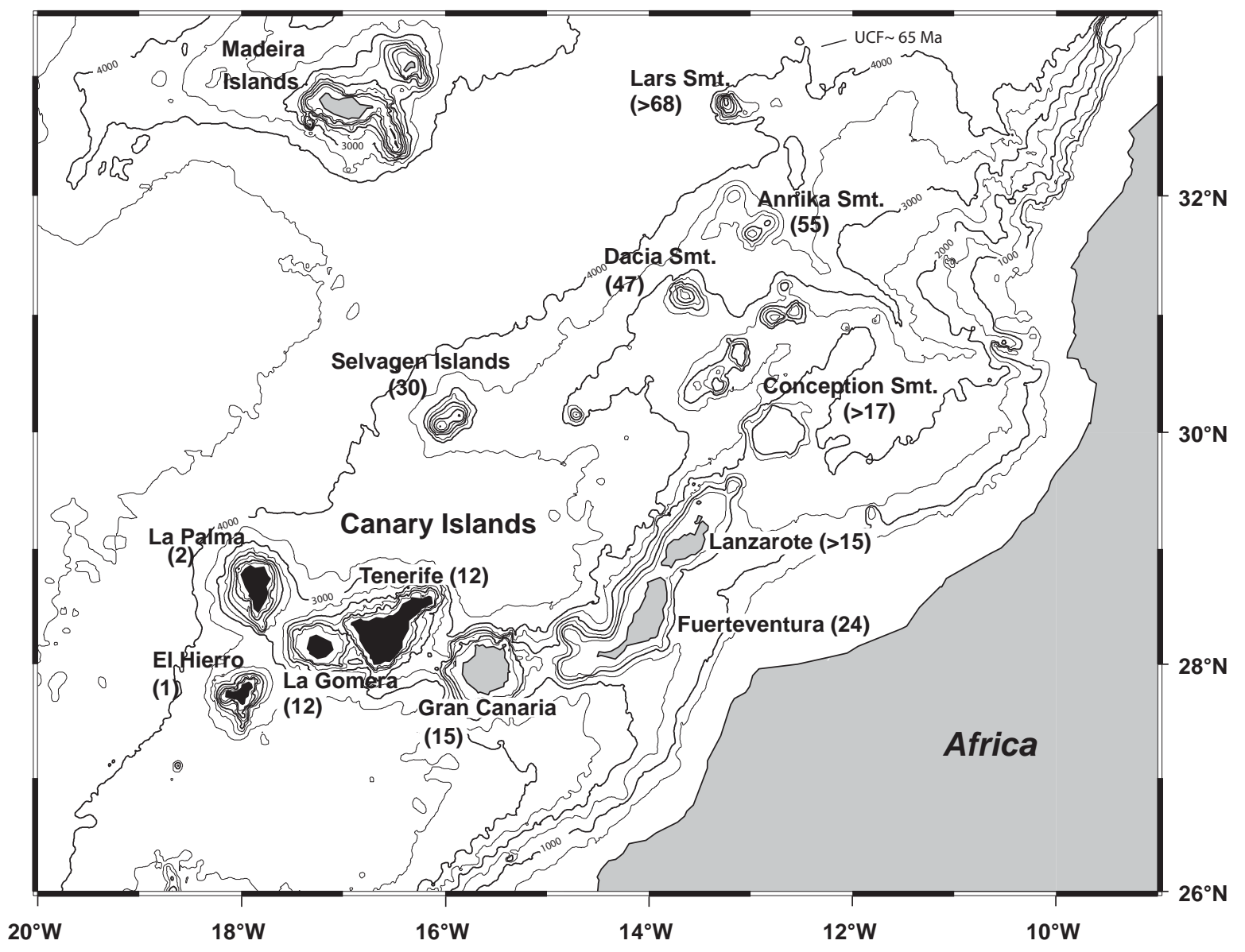

Fig. 1: Gurenko et al. 
(A)

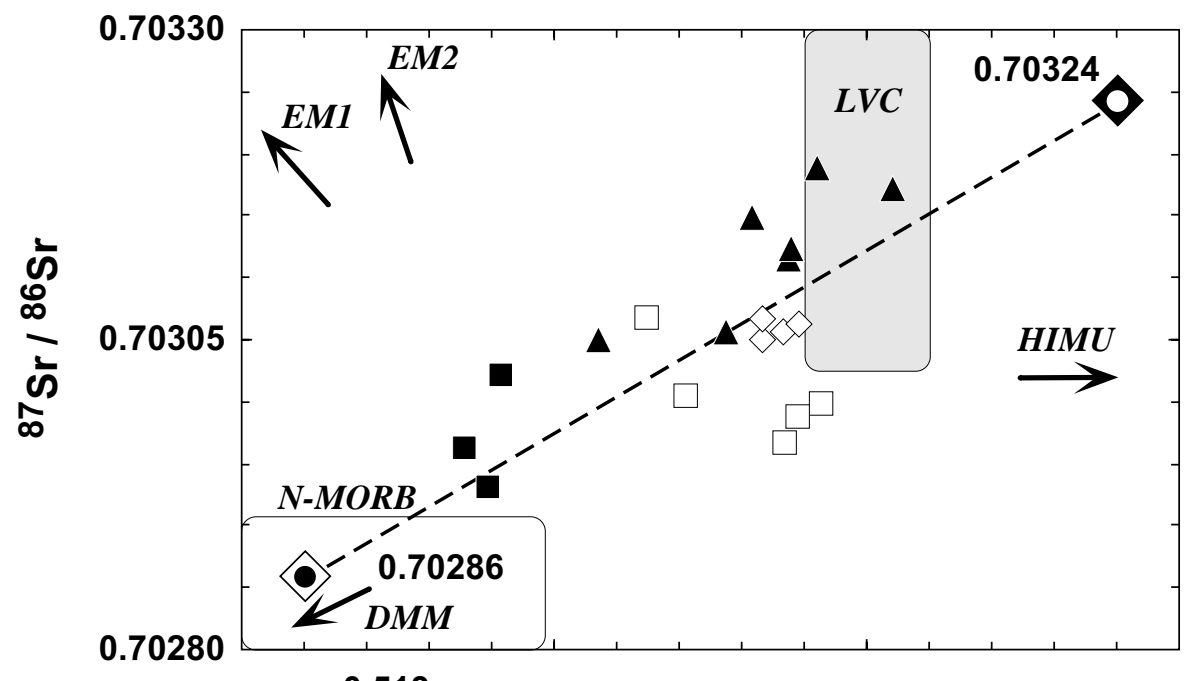

(B)

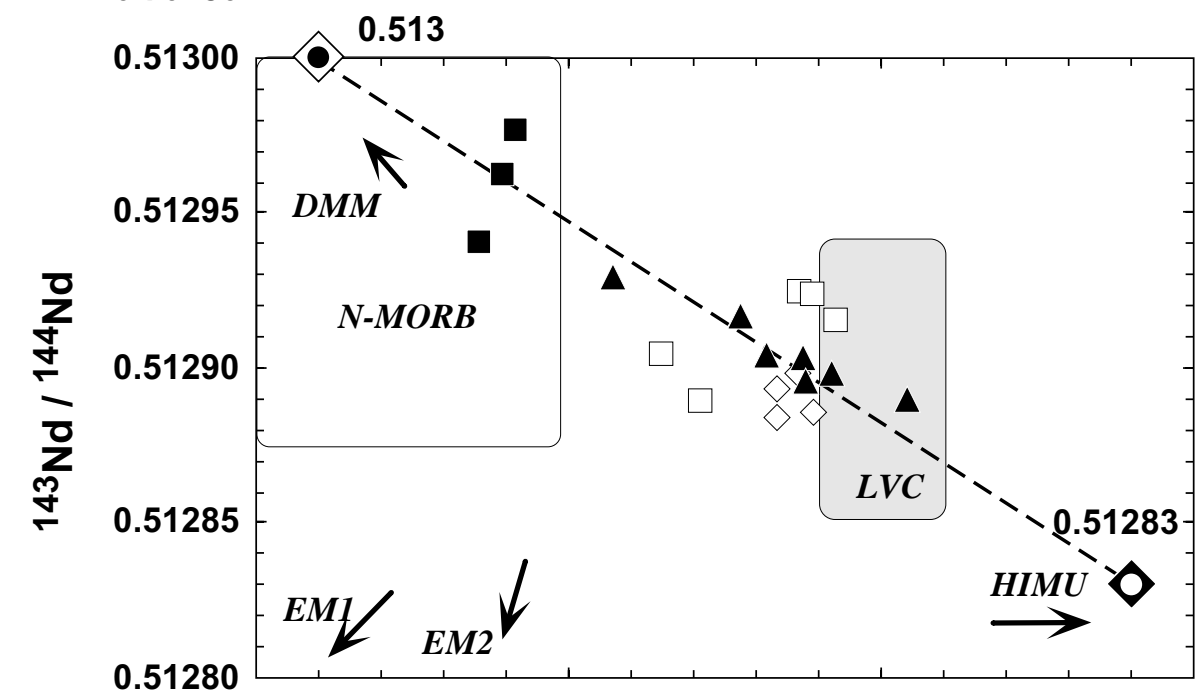

(C)

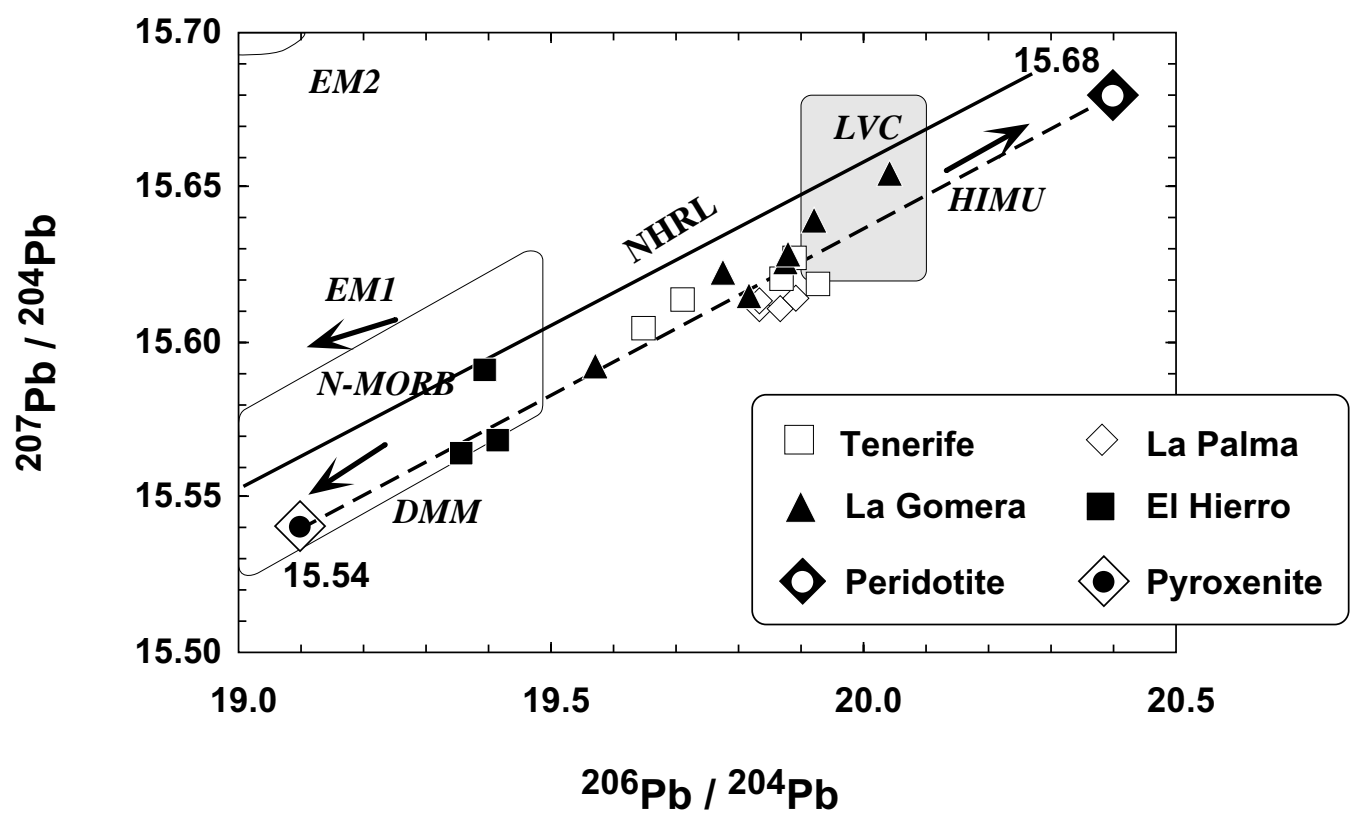

Fig. 2. Gurenko et al. 


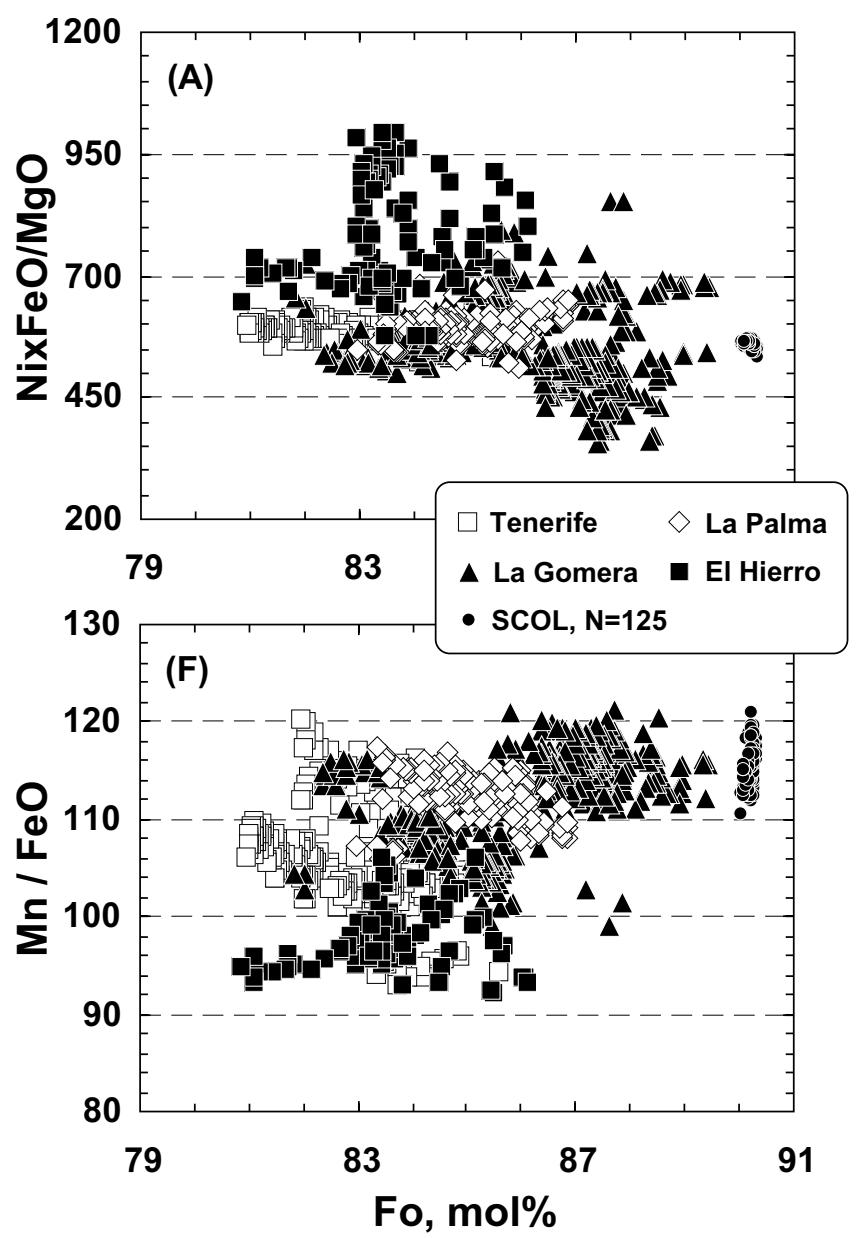

Fig. 3: Gurenko et al. 

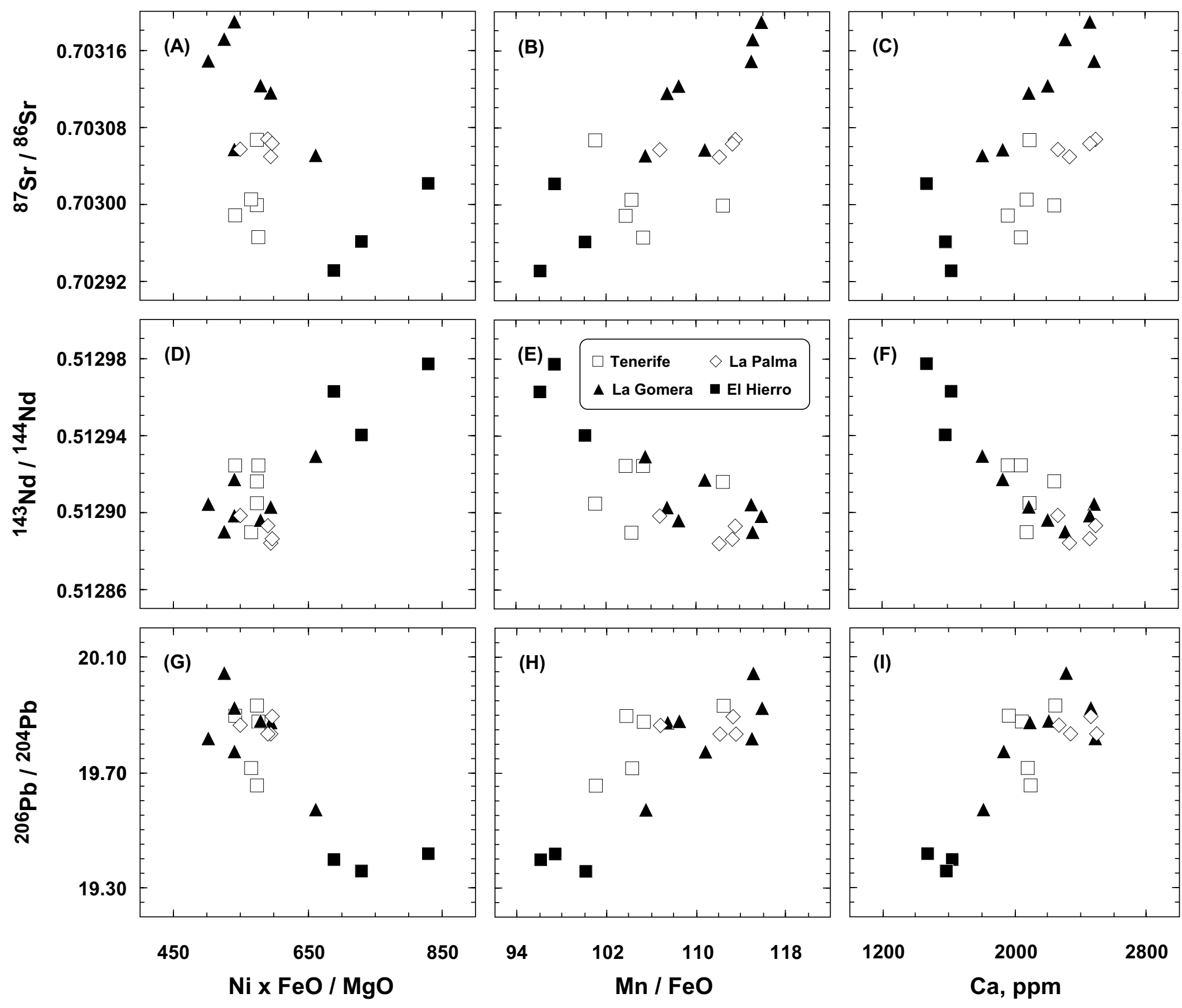

Fig. 4: Gurenko et al. 

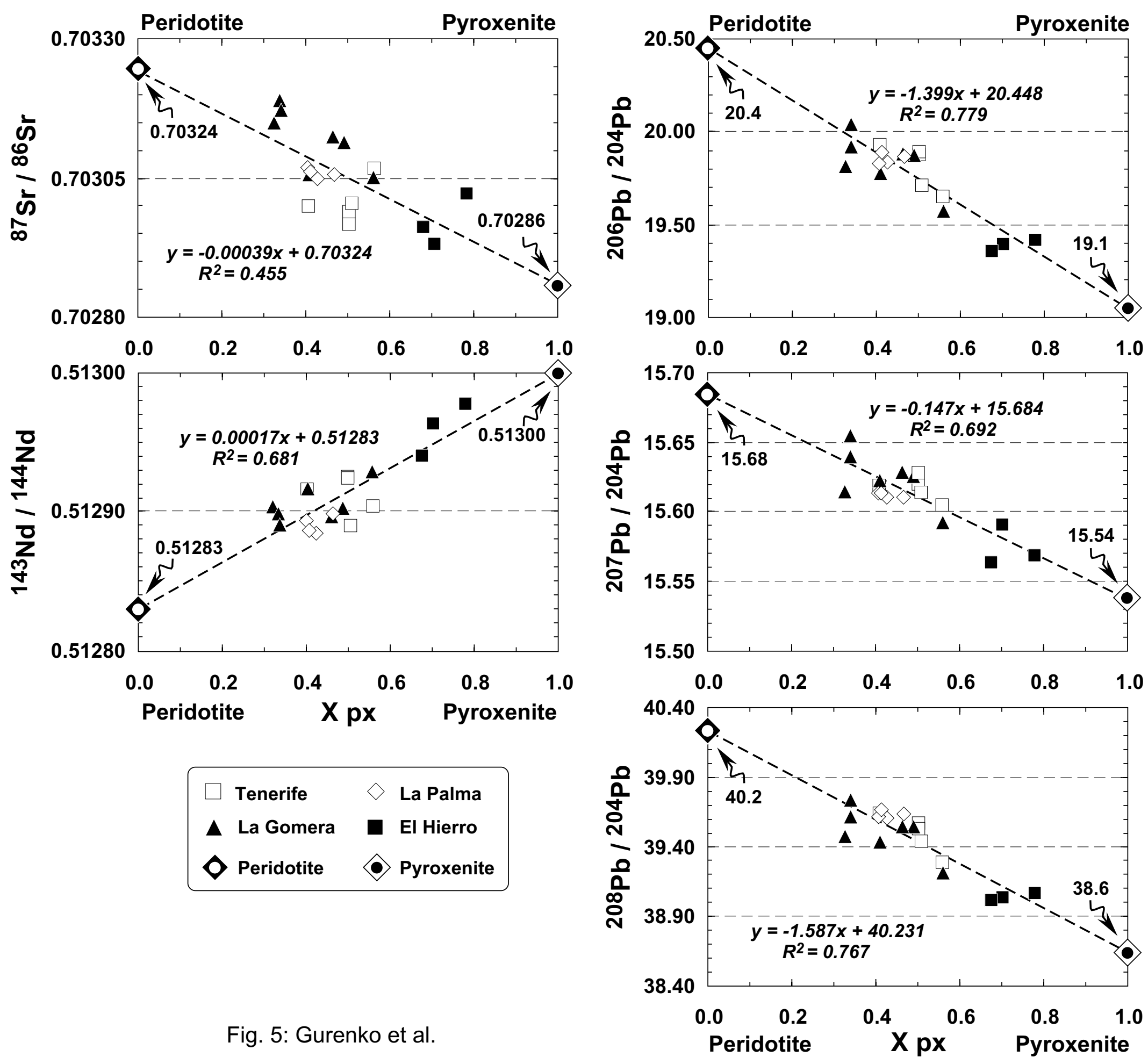

Fig. 5: Gurenko et al.

$\begin{array}{lll} & & \\ \text { Peridotite } & \mathrm{X} \mathrm{px} & \text { Pyroxenite }\end{array}$

